\title{
DUALITY OF CORDIERITE GRANITES RELATED TO MELT-RESTITE SEGREGATION IN THE PEÑA NEGRA ANATECTIC COMPLEX, CENTRAL SPAIN
}

\author{
M. DOLORES PEREIRA GÓMEZ ${ }^{\S}$ AND M. DOLORES RODRÍGUEZ ALONSO§ \\ Departamento de Geología (Petrología y Geoquímica), Facultad de Ciencias, \\ Universidad de Salamanca, E-37008 Salamanca, Spain
}

\begin{abstract}
A large anatectic complex of Hercynian age, the Peña Negra complex, crops out in the central-north area of the Sierra de Gredos, Avila batholith, central Spain. Migmatites and anatectic granitic rocks were generated during the Upper Carboniferous from a Neoproterozoic - Lower Cambrian schist-greywacke complex with minor interlayered orthogneisses. Granitic rocks appear as subhorizontal sheets of megacrystic granodiorite and as lenticular bodies of leucogranite. These formed by in situ anatexis and correspond to melt-restite segregations under two different conditions, namely high melt-fraction in the case of the granodiorite, and low melt-fraction in the case of the leucogranites. The leucogranites display large enclaves of sillimanite-rich material, representing the restitic fraction. Granodiorite was generated as consequence of crustal thickening under conditions of $\mathrm{T} \approx 750$ to $800^{\circ} \mathrm{C}$ and $\mathrm{P} \approx 4 \mathrm{kbar}$, coinciding with the second phase of the Hercynian orogeny. After this event, an extensional episode involved smaller degrees of decompression-induced melting, and generated small batches of cordierite leucogranites from an already depleted source. Anatexis was enhanced, in both cases, by shear structures and by the existence of a fertile protolith.
\end{abstract}

Keywords: Hercynian orogeny, Peña Negra Complex, Schist-Greywacke Complex, migmatites, anatexis, cordierite, Spain.

\section{SOMMAIRE}

Un massif anatectique important d'âge hercynien, que nous appelons le complexe de Peña Negra, affleure dans la partie centre-nord de la Sierra de Gredos, batholithe d'Avila, en Espagne centrale. Les migmatites et les roches granitiques anatectiques ont été formées au cours d'un événement carbonifère supérieur aux dépens d'un socle de schistes et grauwackes avec intercalations mineures d'orthogneiss, d'âge néoprotérozoïque ou cambrien inférieur. Les roches granitiques semblent se présenter en feuilles subhorizontales de granodiorite mégacristique et en lentilles de leucogranite. Ces roches ont été formées par anatexie in situ et illustreraient une ségrégation du liquide silicaté de la fraction résiduelle sous deux régimes différents, le premier impliquant une fraction de liquide élevée (cas de la granodiorite) et l'autre, une fraction de liquide réduite (cas du leucogranite). Les lentilles de leucogranite contiennent de grosses enclaves enrichies en sillimanite, qui représentent la fraction résiduelle. La formation de la granodiorite résulte de l'épaississement de la croûte et a eu lieu entre environ 750 et $800^{\circ} \mathrm{C}$ à une pression de $4 \mathrm{kbar}$, lors de la seconde phase de l'orogenèse hercynienne. Suite à cet événement, une période d'extension a provoqué une fusion plus limitée accompagnant la décompression, et donc a produit de plus petits volumes de leucogranite à cordiérite à partir d'une source déjà rendue relativement stérile. L'anatexie a été favorisée, dans les deux cas, par la présence de structures de cisaillement et d'un protolithe fertile.

(Traduit par la Rédaction)

Mots-clés: orogenèse hercynienne, complexe de Peña Negra, socle de schistes et de grauwackes, migmatites, anatexie, cordiérite, Espagne.

\section{INTRODUCTION}

The Avila batholith consists of a large number of granitic bodies, most of which may be classified chemically and petrographically as S-type granites. The Peña Negra anatectic complex, the subject of our investiga- tion, could represent the level at which these granites were produced. The Peña Negra anatectic complex (PNAC: Bea \& Pereira 1990, Pereira 1992, Pereira \& Bea 1994) is located in the middle part of the Gredos sector (Fig.1). It comprises high-grade metamorphic rocks, mostly migmatites, and autochthonous or

§E-mail addresses: mdp@gugu.usal.es, mdra@gugu.usal.es 
subautochthonous granitic bodies. These bodies occur either as small, lens-shaped domains or as subhorizontal sheets interlayered with the migmatites. The PNAC has a subhorizontal orientation due to the second phase of Hercynian deformation, and exhibits subhorizontal structures such as isoclinal folds, foliation and shear zones. This complex is surrounded by several granite plutons with contacts ranging from concordant to intrusive (Fig. 2).

The Schist-Greywacke Complex (SGC) has been documented (e.g., Díez Balda 1980, Rodríguez Alonso 1985, Beetsma 1995) in the northwestern part of the Iberian Central System. It comprises Neoproterozoic Lower Cambrian metasedimentary rocks considered as a possible protolith of the Peña Negra complex, as well as of many other granitic complexes in central Iberia (Ramírez \& Grundvig 2000).

Our aim in this paper is to present the contrasting geochemical evolution of the two anatectic granitic rocks, granodiorites and leucogranites, that form part of the Peña Negra complex, together with a synthesis of the compositional characteristics of the rocks involved in the study. Specifically, major, trace element and oxygen isotope compositions of the anatectic rocks and their potential source-rocks are compared. We attempt to identify the processes involved in the generation of these granitic rocks and the evidence for postulating a metasedimentary protolith.

\section{Geological Background}

\section{Regional setting}

The PNAC covers an area of more than $350 \mathrm{~km}^{2}$ in the Central Iberian Zone, within the confines of the Avila batholith (Fig. 1). This batholith crops out over a section of $13,000 \mathrm{~km}^{2}$ in the middle axial part of the Hercynian Massif, in the western part of the Iberian Peninsula (Julivert et al. 1972). It has been divided into two sectors according to lithology and age, Gredos

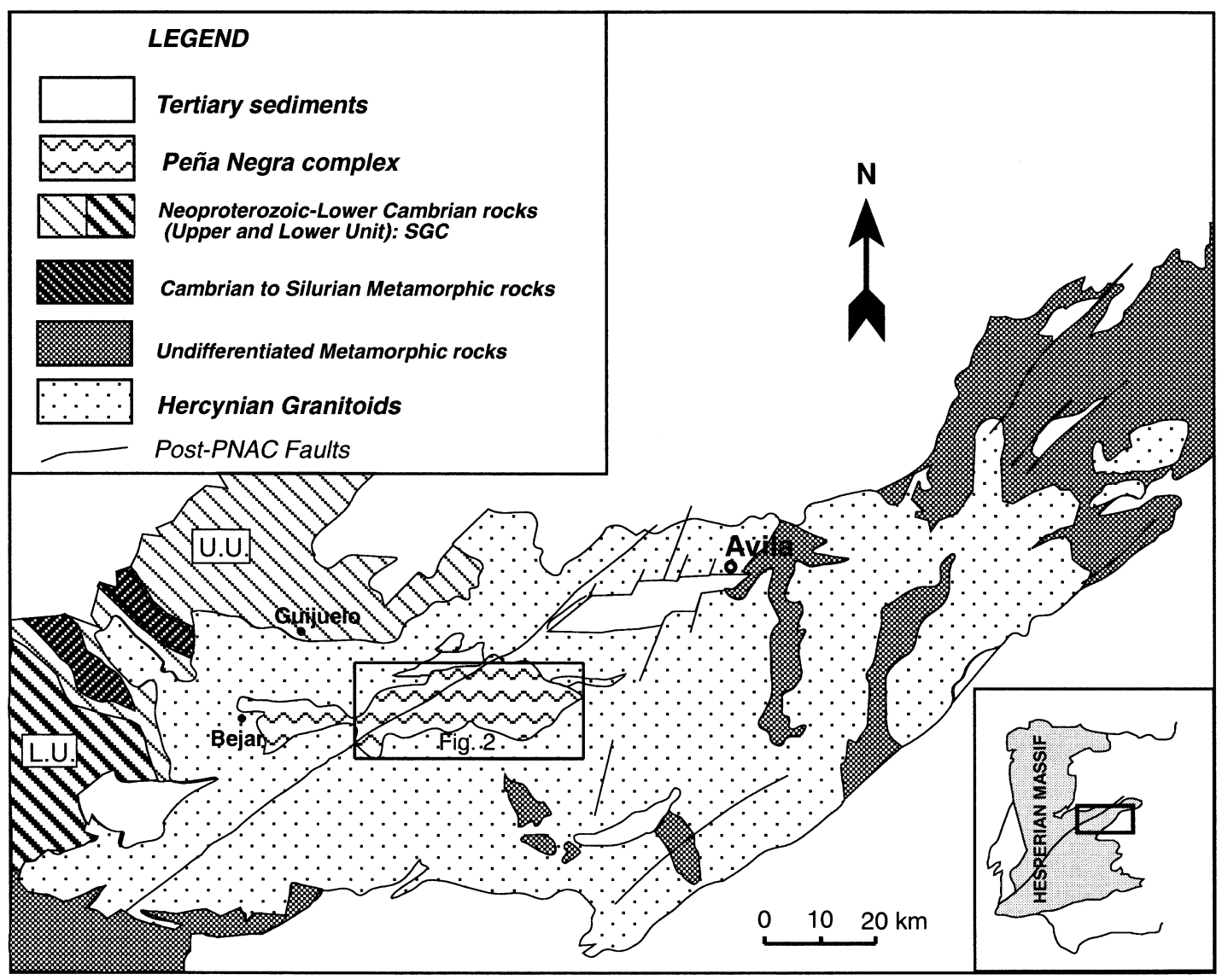

FIG. 1. Location of the Peña Negra anatectic complex within the Avila batholith (Central Iberia zone, Hercynian Massif), and the Schist-Greywacke complex (SGC). U.U.: Upper Unit; L.U.: Lower Unit. 


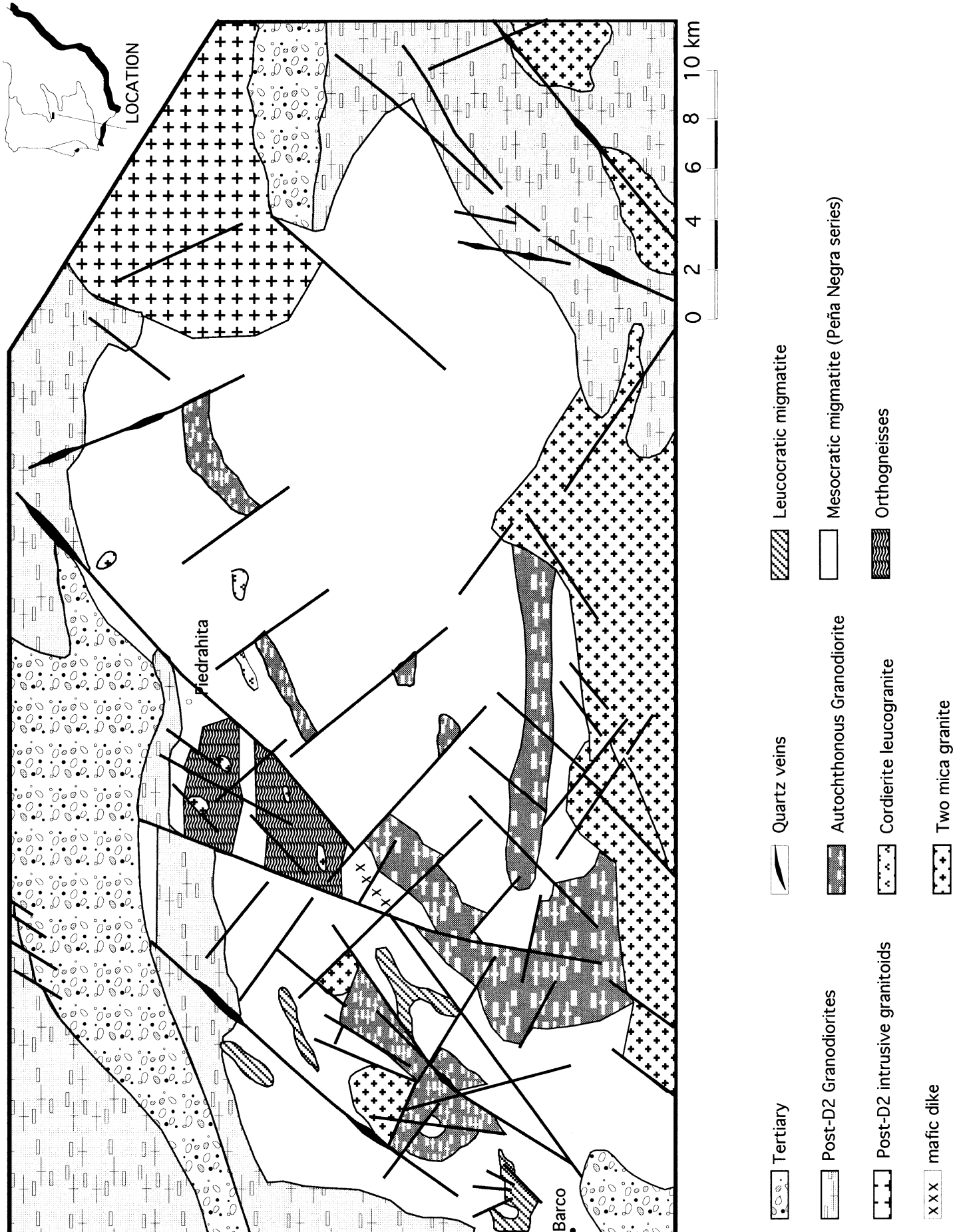

FIG. 2. Geological sketch of the Peña Negra complex. See text for description of rock types. 
(western part) and Guadarrama (eastern part: Fuster \& Villaseca 1979, Bea 1985, Ibarrola et al. 1987). The Gredos sector is composed of coalesced plutons of strongly peraluminous, porphyritic granodiorites and monzogranites, together with large anatectic complexes (e.g., the PNAC). Most of the granitic rocks are synkinematic with respect to the second phase of the Hercynian deformation, and their age is around $310 \mathrm{Ma}$. This age also dates the episode of the volumetrically most important anatexis (Pereira et al. 1992, see below).

The PNAC consists mainly of migmatites, granodiorites, leucogranites, orthogneisses and sillimaniterich restite. Gabbros and diorites can be found as small outcrops in a nearby area, cut by the granodiorites, but they have not interacted with them.

\section{Field relations, petrography and mineralogy of the Peña Negra rock types}

In terms of volume, migmatites represent the most important rock-type in the PNAC (Pereira 1989, Bea \& Pereira 1990, Bea 1991, Pereira 1992). In outcrop, they appear as mesocratic rocks composed of a granodioritic leucosome (quartz, plagioclase, K-feldspar, cordierite and biotite), and a melanosome, made up of sillimanite, biotite and cordierite, locally with a high content of ilmenite, which shows up as small enclaves or schlieren interlayered with the leucosome. Depending on the mesoscopic aspect of the mesocratic migmatites, we have described three different facies: 1) schlieren, 2) nebulitic and 3) transitional. Each facies has the same mineralogy and bulk composition, but differs in texture. These rocks were affected by the same petrogenetic process, but with different degrees of segregation and textural evolution. The schlieren facies has centimetric compositional layering defined by melanocratic and leucocratic layers. In places, the schlieren display complex folding, giving so-called "wild migmatite", which exhibits subhorizontal deformation attributed to the second phase of the Hercynian Orogeny. Nebulitic and transitional facies also reveal the subhorizontal structures, albeit to a lesser extent, because the higher intensity of anatexis has caused a partial obliteration. Transitional facies show up in the transition between migmatites and granodiorites, and the contact is invariably gradational. This facies has some feldspar phenocrysts, which is the main petrographic feature of the granodiorites, and ultimately it is difficult to determine whether they should be called migmatites or diatexitic granodiorites. Relative textural maturity was established on the different facies of migmatites using the approach of McLellan (1983); the results (Bea \& Pereira 1990) indicate that the degree of anatexis increases from the schlieren to the nebulitic and transitional facies.

Porphyritic granodiorite crops out as medium- to coarse-grained rocks, with abundant tabular K-feldspar megacrysts and prismatic, commonly chloritized cordierite. The fabric of the granodiorites is subhorizontal, concordant with the migmatites and the general structure of the PNAC, and displays a strong subhorizontal foliation defined by feldspar megacrysts, biotite and prismatic cordierite (Fig. 3).

Mineralogical compositions of the migmatites and granodiorites are similar. Both contain quartz, plagioclase (migmatites: core $\mathrm{An}_{33-18}$, rim $\mathrm{An}_{18-12}$; granodiorite: core $\mathrm{An}_{30-29}$, rim $\mathrm{An}_{17-12}$ ), alkali feldspar, biotite, cordierite and sillimanite as principal phases. The leucosomes of migmatites have a hypidiomorphic texture, composed of quartz + plagioclase + cordierite + biotite + alkali feldspar. The melanosome is composed of alternating granoblastic (cordierite \pm quartz \pm plagioclase \pm alkali feldspar) and schistose (sillimanite + biotite + ilmenite \pm cordierite) layers. All these rocks contain accessory apatite, zircon, ilmenite, tourmaline, monazite and xenotime. Garnet is present as a minor phase in one outcrop of the schlieren migmatites. This outcrop is located in a narrow band, coinciding with the largest outcrop of cordierite leucogranite generated from melting of the migmatites. Specific studies on this outcrop are being carried out to understand this anomaly (Pereira et al., in prep.).

Leucogranites are commonly spatially related to the mesocratic migmatites. They consist of cordierite-bearing leucocratic rocks that outcrop as small bodies within the migmatites, with contacts ranging from transitional to intrusive (Figs. 4a, b: Bea 1991). These rocks are made up of quartz, alkali feldspar, plagioclase (core $\mathrm{An}_{25-20}$, rim $\mathrm{An}_{17-13}$ ) and cordierite, with the same accessory minerals as in the granodiorites and migmatites. Cordierite is commonly euhedral to subhedral. Locally, very small (less than $1 \mathrm{~m}$ diameter) intrusive bodies of a garnet leucogranite occur; they are unrelated to the anatexis.

Orthogneisses occur as narrow bands interlayered with the migmatites. They are leucocratic, strongly foliated, and show the structures produced by the different phases of the Hercynian deformation (Díez Balda et al. 1990). Orthogneisses have been affected by several stages of migmatite formation (Pereira 1992), and augen structures are common. These rocks consist of quartz, plagioclase (core $\mathrm{An}_{37}$, rim $\mathrm{An}_{33}$ ), alkali feldspar and biotite, with zircon, apatite, monazite and ilmenite as accessory phases. Muscovite and chlorite occur as secondary products.

Sillimanite-rich restite forms irregular, small bodies typically in contact with the granodiorites, and are characterized by conspicuous crystals of sillimanite $3-4 \mathrm{~cm}$ long. These restites have a granoblastic texture, and the modal content of sillimanite ranges between 30 and $60 \%$. The mineral assemblage is as in the melanosomes. In addition to sillimanite, biotite and cordierite occur as principal phases, augmented by quartz and feldspar. Ilmenite (locally abundant), pyrite, muscovite, zircon and apatite represent accessory phases that are commonly hosted by biotite crystals. 


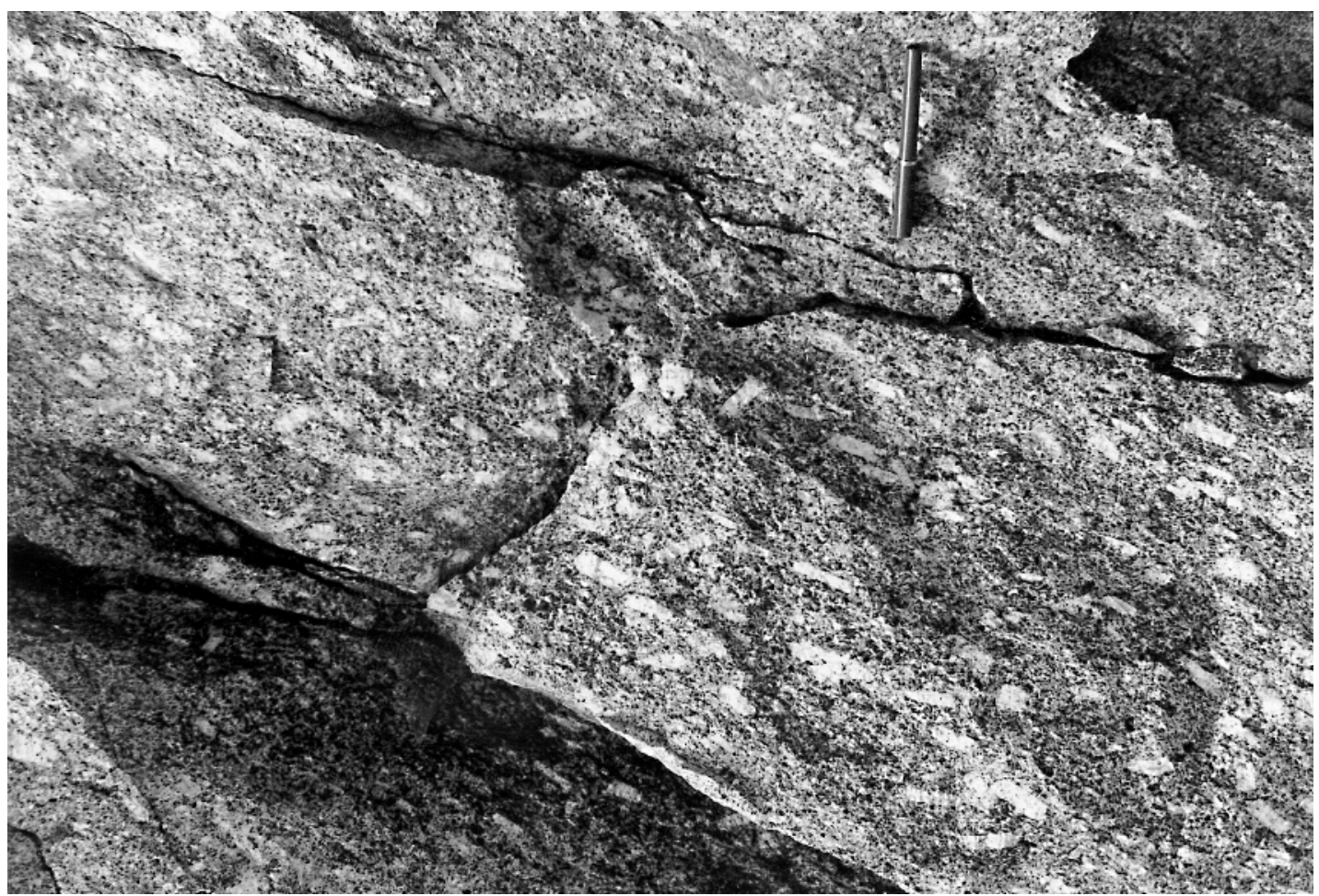

FIG. 3. Typical exposure of the subautochthonous porphyritic granodiorite.

\section{Field relations, petrography and mineralogy of the protolith}

Carbonate and calc-silicate lenses within the migmatitic series indicate that the migmatites of the PNAC were derived from a metasedimentary source (Pereira 1992). Field relationships suggest that the Neoproterozoic - Lower Cambrian metasedimentary rocks within the extensive antiforms (between very narrow Ordovician synclines at the northern and western part of the PNAC area) are the potential source for the migmatites and other Hercynian granites. These metasedimentary rocks, known as the Schist-Greywacke Complex (SGC), are characterized by a very thick sandstone-mudstone sequence with some conglomeratic and carbonate intercalations. This complex grades upward into a Lower Cambrian sandy and carbonate facies (Tamames Sandstone and Tamames Limestone formations) with trilobites, archeocyaths and ichnofossils. All are unconformably overlain by Ordovician-Silurian metasedimentary rocks (Díez Balda 1980, Nozal \& Robles 1988).

Two different main units, described in the SGC (Rodríguez Alonso 1985), can also be distinguished throughout the Central Iberian Zone. The Lower Unit is lithologically monotonous and occupies the western part of the PNAC area (containing low-grade metamorphic assemblages), whereas the Upper Unit outcrops mainly toward the northwestern part and constitutes a varied lithological succession that includes a more intensely metamorphosed and tectonized nucleus (MartinamorCastellanos Antiform) in which orthogneiss and granites intruded the pre-Ordovician formations. The whole stratigraphic sequence is interpreted as representing continuous siliciclastic sedimentation with the development of a turbiditic facies, which evolved upward into a mixed siliciclastic rock - carbonate slope-platform sedimentation, within an area of relative tectonic instability associated with volcanic activity (Rodríguez Alonso 1985, Vidal et al. 1994, Rodríguez Alonso \& Palacios 1994, Rodríguez Alonso \& Alonso Gavilan 1995).

The Lower Unit is generally devoid of marker beds and is composed of alternating sandstones and mudstones, with some intercalation of conglomerates and disordered levels. The Upper Unit comprises a predominantly grey, muddy succession with several levels of black mudstones, conglomerates and sandstones as well as some discontinuous siliciclastic rock - carbonate strata and olistostromes. Other rock units described from the Upper Unit include phosphate-rich layers, volcan- 

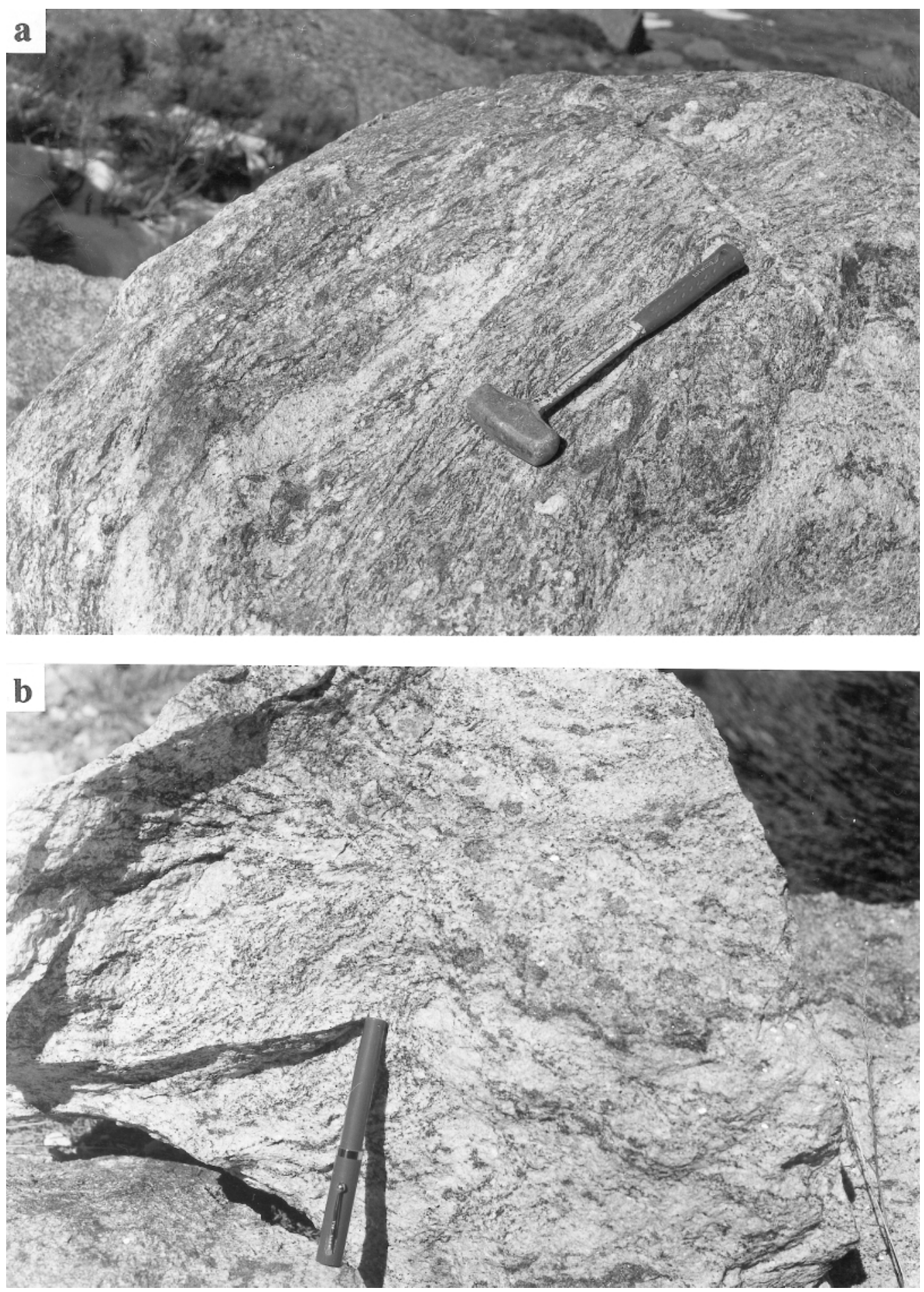

FIG. 4. Outcrop photographs of cordierite leucogranite. a) Small batches with transitional contacts with the migmatites. b) The leucogranite shows an intrusive contact with respect to the migmatite. Cordierite crystals are obvious because they are rather altered. 
iclastic, calc-silicate and amphibolitic strata, each showing conspicuous lateral variations in facies. This sequence is enriched in quartz and feldspar phases toward the northwestern part of the PNAC area, where two informal lithostratigraphic units have been described: Monterrubio and Aldeatejada Formations (Díez Balda 1980). This area was affected by intensive Hercynian deformation, with the development of a medium- to high-grade metamorphism that induced anatexis in some areas.

The Monterrubio Formation outcrops in the core of phase I and III Variscan antiforms, and consists of sandy mudstones and laminated carbonaceous black mudstones, with some quartz arenite and conglomerate intercalations. Some feldspathic conglomerates have been named "porphyroids" by Martínez García \& Nicolau (1973), which implies a derivation from an andesiterhyodacite provenance, in order to indicate their genesis from volcanic rocks, together with intercalations of andesites and rhyodacites. Amphibolites and calc-silicate rocks also are present (García de Figuerola \& Franco 1975). Phosphate clasts are common and constitute good marker-horizons. The estimated thickness of this formation is $2,000 \mathrm{~m}$. It represents sedimentation in a siliciclastic platform environment (sensu lato) with repeated changes in sea level and evidence of wave action (Nozal \& Robles 1988). The boundary with the overlying Aldeatejada Formation is gradational.

The Aldeatejada Formation, which has an estimated thickness of more than $2,000 \mathrm{~m}$, consists of siltstones and mudstones with fine intercalations of sandstones, carbonates (limestones, breccias, conglomerates and nodules) and calc-silicate rocks, together with black laminated carbonaceous to grey mudstone interbeds. The latter constitute a good marker-horizon, with some nodules or thin layers rich in phosphate. They have been interpreted as contourite deposits (Oczlon \& Díez Balda 1992) in a platform environment that evolved to nearshore sandstone facies in the Tamames Sandstone Formation (Nozal \& Robles 1988), straddling the Precambrian-Cambrian boundary (Rodríguez Alonso \& Alonso Gavilán 1995).

Mudstones and their metamorphic equivalents are the most abundant group, augmented by minor sandstone, conglomerate and carbonate intercalations. Phosphate-rich rocks and cherts also are present. In areas of low metamorphic grade, original textures can be recognized, although most rocks are recrystallized and deformed. Evidence of magmatism contemporaneous with sedimentation is provided by volcanogenic lithic fragments and crystals mixed in different proportions with siliciclastic constituents within volcanoclastic and calcsilicate rocks. Outcrops with amphibolites, quartziferous amphibolites and rhyolites also occur. Textures, mineralogy and chemical composition of these lowgrade rocks confirm their relationship with calc-alkaline magmatism that involved rhyolite, andesites and basalts (Rodríguez Alonso 1985).
Mudstones comprise a fine groundmass of phyllosilicates (chlorite, muscovite) with varied proportions of silt and fine-grained quartz sand. Accessory minerals are feldspar, biotite, opaque phases, tourmaline, zircon and apatite. Some samples show a fine lamination, containing abundant carbonaceous material, giving a darker color to the sample. Occasionally, we can find phosphate-rich horizons or nodules.

Among the sandstones, we include quartz arenites, lithic sandstones, quartz, lithic and feldspathic graywackes and volcanoclastic sandstones. Conglomerates are both grain- and matrix-supported, and also oligoand polymictic in composition. The mineralogy of the sandstones and conglomerates reveals different provenance areas for the rock fragments and quartz grains: sedimentary (siliciclastic), metamorphic and igneous (plutonic and volcanic).

Calc-silicate rocks are considered volcaniclastic, with clastic textures in the sand-size grains, made up mainly of quartz, plagioclase and fragments of intermediate igneous rock (with a microcrystalline texture and an assemblage of quartz + plagioclase + tremolite \pm actinolite) similar to that in the quartziferous amphibolite rocks. They have abundant interstitial matter of the same composition as the fragments, where irregular crystals of plagioclase can be found interacting with grains of quartz and feldspar.

Among the carbonate materials are crystalline laminated limestones and dolomites with very few allochemical components and small quantities of quartz and pyrite, together with fragments of pelitic rock and acid volcanic rock fragments. Other accessory phases are feldspar, tourmaline, zircon, apatite, muscovite, biotite, chlorite, opaque minerals, titanite and clinozoisite.

Quartz-bearing amphibolite presents a microcrystalline laminated texture. Opaque grains, calcite and epidote are disposed as fine and aligned aggregates. The microcrystalline groundmass is made up of a feldspathic aggregate with scarce quartz in which amphibole (actinolite-tremolite) shows a fasciculate texture, and clinozoisite is found as idiomorphic or irregular aggregates together with epidote and opaque phases.

\section{Whole-Rock GeOchemistry}

\section{Analytical methods}

Concentrations of major elements in whole-rock samples were established by optical emission spectrometry (ICP-OES), and of $\mathrm{Na}$ and $\mathrm{K}$, by atomic absortion spectrometry (AA) at the University of Salamanca (Spain). Analytical precision was about $\pm 0.25 \%$ rel., $\pm 0.75 \%$ rel. and $\pm 2.5 \%$ rel. for analyte concentrations of $10 \mathrm{wt} \%, 1 \mathrm{wt} \%$ and $0.1 \mathrm{wt} \%$, respectively. Concentrations of trace elements and rare-earth elements (REE) were determined by mass spectrometry (ICP-MS) at the laboratory of Perkin Elmer in Uberlingen (Germany); the precision was about $\pm 2 \%$ rel. and $\pm 5 \%$ rel. for 
analyte concentrations of 50 and 5 ppm, respectively. For analytical comparison, some of the samples were analyzed by instrumental neutron activation analysis (INAA) at the nuclear reactor of McMaster University (Canada). Analyses for boron were done by prompt gamma neutron-activation analysis (PGNAA) at McMaster University (Canada). A description of the method can be found in Pereira \& Shaw (1997).

Oxygen isotope analyses were performed at the University of Saskatchewan (Canada). The compositions were measured using the $\mathrm{BrF}_{5}$ technique of Clayton \& Mayeda (1963).

\section{Results}

Major-element compositions of mesocratic migmatites and subautochthonous granodiorites are almost identical (Table 1). Their compositions plot between the granodiorite and granite fields on the An-Ab-Or diagram. The migmatites are particularly heterogeneous. The $\mathrm{SiO}_{2}$ content of the migmatites and granodiorites ranges from 60.56 to $67.08 \% . \mathrm{Al}_{2} \mathrm{O}_{3}$ contents range between 10.02 and $16.72 \%$. The average value of $\mathrm{CaO}$, $\mathrm{Na}_{2} \mathrm{O}$ and $\mathrm{K}_{2} \mathrm{O}$ are $1.51 \%$ (2.57\% for granodiorites), $2.59 \%$ and $3.92 \%$ (4.36\% for granodiorites), respec-

TABLE 1. COMPOSITION OF SAMPLES OF THE PEÑA NEGRA ANATECTIC COMPLEX (PNAC) AND ITS PROTOLITH

\begin{tabular}{|c|c|c|c|c|c|c|c|c|c|c|c|c|}
\hline Ref. & $\mathrm{SiO}_{2}$ & $\mathrm{TiO}_{2}$ & $\mathrm{Al}_{2} \mathrm{O}_{3}$ & $\mathrm{FeOT}$ & $\mathrm{MgO}$ & $\mathrm{MnO}$ & $\mathrm{CaO}$ & $\mathrm{Na}_{2} \mathrm{O}$ & $\mathrm{K}_{2} \mathrm{O}$ & $\mathrm{P}_{2} \mathrm{O}_{5}$ & $\mathrm{H}_{2} \mathrm{O}$ & Rock type \\
\hline B-304 & 62.71 & 0.69 & 18.32 & 5.27 & 2.08 & 0.06 & 1.60 & 2.91 & 4.29 & 0.33 & 1.56 & $\mathbf{M}$ \\
\hline B-305 & 71.06 & 0.42 & 14.90 & 2.63 & 1.01 & 0.04 & 1.35 & 3.26 & 4.40 & 0.29 & 0.34 & $\mathbf{M}$ \\
\hline B-307 & 60.94 & 0.77 & 18.29 & 6.75 & 3.08 & 0.11 & 1.49 & 2.77 & 3.55 & 0.17 & 1.84 & $\mathbf{M}$ \\
\hline B-320 & 66.21 & 0.62 & 17.35 & 4.72 & 1.90 & 0.06 & 1.40 & 2.30 & 3.92 & 0.23 & 0.84 & M \\
\hline B-339 & 65.01 & 0.87 & 18.60 & 5.69 & 2.40 & 0.09 & 1.07 & 2.37 & 3.49 & 0.18 & 0.00 & $\mathbf{M}$ \\
\hline B-341 & 70.12 & 0.61 & 15.07 & 3.67 & 1.64 & 0.08 & 1.37 & 2.63 & 3.13 & 0.18 & 1.07 & $\mathbf{M}$ \\
\hline B-342 & 68.00 & 0.71 & 16.05 & 3.94 & 1.97 & 0.09 & 1.12 & 2.37 & 3.67 & 0.14 & 1.60 & $\mathbf{M}$ \\
\hline B-343 & 67.82 & 0.65 & 16.50 & 3.49 & 1.55 & 0.06 & 1.08 & 2.89 & 4.29 & 0.11 & 1.33 & $\mathbf{M}$ \\
\hline B-344 & 68.89 & 0.73 & 14.76 & 2.11 & 0.78 & 0.05 & 0.99 & 2.39 & 6.57 & 0.55 & 1.86 & $\mathbf{M}$ \\
\hline B-345 & 65.22 & 0.79 & 17.22 & 4.79 & 1.95 & 0.11 & 1.32 & 2.82 & 4.02 & 0.11 & 1.45 & $\mathbf{M}$ \\
\hline LO-14 & 72.67 & 0.25 & 14.38 & 1.31 & 0.28 & 0.03 & 0.62 & 3.01 & 5.10 & 0.42 & 1.79 & $\mathbf{M}$ \\
\hline LO-16 & 60.56 & 1.25 & 17.27 & 5.64 & 2.31 & 0.06 & 3.79 & 3.19 & 2.98 & 0.38 & 1.69 & $\mathbf{M}$ \\
\hline LO-18 & 66.15 & 0.77 & 17.16 & 4.64 & 1.57 & 0.06 & 1.94 & 2.48 & 3.34 & 0.16 & 0.98 & $\mathbf{M}$ \\
\hline LO-25 & 64.64 & 0.89 & 17.03 & 5.77 & 1.87 & 0.07 & 1.65 & 1.97 & 3.54 & 0.16 & 1.98 & $\mathbf{M}$ \\
\hline LO-3 & 64.50 & 0.82 & 15.64 & 4.63 & 1.65 & 0.06 & 2.23 & 2.85 & 4.07 & 0.34 & 2.51 & $\mathbf{M}$ \\
\hline LO-4 & 78.75 & 0.34 & 10.02 & 2.10 & 0.99 & 0.04 & 0.94 & 3.18 & 2.31 & 0.15 & 1.19 & $\mathbf{M}$ \\
\hline B-516 & 63.03 & 0.95 & 16.46 & 5.00 & 1.77 & 0.06 & 2.95 & 2.96 & 4.07 & 0.19 & 1.76 & GD \\
\hline LO-17 & 63.41 & 0.96 & 15.95 & 4.57 & 1.57 & 0.00 & 4.24 & 3.07 & 4.15 & 0.21 & 1.56 & GD \\
\hline B-381 & 68.01 & 0.62 & 15.02 & 2.98 & 0.80 & 0.03 & 2.02 & 3.02 & 4.53 & 0.34 & 1.63 & GD \\
\hline B-382 & 65.17 & 1.01 & 15.41 & 5.43 & 1.82 & 0.05 & 1.91 & 2.51 & 3.50 & 0.30 & 1.29 & GD \\
\hline B-400 & 65.45 & 0.95 & 15.69 & 4.72 & 1.72 & 0.06 & 2.83 & 2.98 & 3.32 & 0.35 & 1.17 & GD \\
\hline LO-23 & 64.63 & 0.59 & 17.74 & 4.14 & 1.47 & 0.06 & 0.53 & 1.65 & 4.86 & 0.21 & 3.56 & GD \\
\hline B-306 & 71.58 & 0.22 & 14.90 & 1.78 & 0.54 & 0.04 & 1.27 & 3.57 & 3.96 & 0.30 & 1.47 & $\mathrm{CL}$ \\
\hline B-309 & 65.96 & 0.84 & 16.58 & 5.45 & 2.04 & 0.07 & 1.24 & 1.89 & 3.49 & 0.32 & 1.87 & CL \\
\hline B-322 & 69.37 & 0.51 & 15.57 & 3.56 & 1.41 & 0.06 & 1.01 & 3.74 & 3.80 & 0.14 & 0.23 & 0 \\
\hline B-374 & 66.10 & 0.74 & 17.94 & 3.72 & 0.76 & 0.06 & 3.31 & 3.66 & 3.03 & 0.18 & 0.33 & 0 \\
\hline B-375 & 65.17 & 0.56 & 19.03 & 2.84 & 0.57 & 0.05 & 2.90 & 3.93 & 4.06 & 0.18 & 0.31 & 0 \\
\hline B-376 & 69.58 & 0.47 & 16.57 & 2.32 & 0.46 & 0.04 & 2.55 & 3.47 & 3.67 & 0.16 & 0.34 & 0 \\
\hline B-377 & 68.74 & 0.42 & 16.57 & 2.24 & 0.42 & 0.04 & 2.81 & 3.58 & 3.62 & 0.16 & 0.97 & O \\
\hline B-378 & 70.30 & 0.42 & 15.62 & 2.16 & 0.40 & 0.05 & 2.61 & 3.48 & 3.65 & 0.15 & 0.65 & O \\
\hline LO-26 & 68.01 & 0.69 & 16.04 & 4.13 & 1.61 & 0.06 & 1.62 & 2.64 & 4.31 & 0.16 & 0.34 & O \\
\hline LO-27 & 67.93 & 0.68 & 15.42 & 4.62 & 1.74 & 0.07 & 1.39 & 2.15 & 3.65 & 0.16 & 1.59 & $\mathrm{O}$ \\
\hline LR-379 & 61.71 & 0.48 & 17.39 & 5.17 & 2.96 & 0.05 & 0.67 & 1.01 & 3.80 & 0.31 & 6.54 & Pel + Ph \\
\hline LR-350 & 58.32 & 0.85 & 20.18 & 8.91 & 1.79 & 0.05 & 0.17 & 0.87 & 3.90 & 0.32 & 4.98 & $\mathrm{Pel} .+\mathrm{Ph}$ \\
\hline LR-458 & 66.49 & 0.72 & 14.95 & 9.93 & 0.65 & 0.03 & 0.22 & 0.07 & 3.45 & 0.16 & 3.19 & Con $+\mathrm{Ph}$ \\
\hline LR-396 & 62.13 & 0.73 & 16.94 & 4.80 & 2.47 & 0.08 & 3.29 & 1.18 & 3.99 & 0.32 & 4.04 & Con. $+\mathrm{Ph}$ \\
\hline B-617 & 60.38 & 0.73 & 18.95 & 6.16 & 3.30 & 0.30 & 0.80 & 1.86 & 3.55 & 0.16 & 3.32 & C.P. \\
\hline B-618 & 60.86 & 0.68 & 18.83 & 6.02 & 3.14 & 0.27 & 0.73 & 1.77 & 3.79 & 0.13 & 3.08 & C.P. \\
\hline B-619 & 60.62 & 0.71 & 18.91 & 6.35 & 3.33 & 0.30 & 0.75 & 1.80 & 3.74 & 0.15 & 3.01 & C.P. \\
\hline LR-506 & 51.81 & 0.23 & 15.55 & 7.16 & 9.14 & 0.50 & 13.10 & 0.39 & 1.38 & 0.25 & 0.89 & ANF \\
\hline LR-84 & 68.59 & 0.56 & 14.65 & 5.47 & 1.89 & 0.12 & 2.22 & 4.05 & 0.35 & 0.12 & 1.87 & SAND. \\
\hline LR-392 & 87.15 & 0.11 & 3.68 & 6.77 & 0.06 & 0.03 & 0.03 & 0.07 & 0.18 & 0.08 & 0.74 & SAND. \\
\hline LR-45 & 70.31 & 0.38 & 12.03 & 8.67 & 2.57 & 0.08 & 0.21 & 1.18 & 1.33 & 0.08 & 2.82 & SAND. \\
\hline LR-198 & 75.28 & 0.59 & 11.82 & 1.56 & 0.64 & 0.02 & 0.20 & 1.33 & 2.74 & 0.08 & 5.71 & SAND. \\
\hline LR-190 & 80.36 & 0.59 & 6.02 & 3.76 & 1.93 & 0.10 & 4.31 & 0.57 & 0.55 & 0.25 & 1.18 & VOL. S. \\
\hline LR-140 & 71.46 & 0.83 & 12.12 & 5.21 & 1.85 & 0.08 & 1.26 & 3.58 & 1.42 & 0.15 & 1.32 & VOL. S. \\
\hline
\end{tabular}

PNAC lithologies: M: migmatite, GD: granodiorite, $\mathrm{CL}$ : cordierite leucogranite, $\mathrm{R}$ : restite.

Protolith rock-types: SAND.: sandstone, VOL. S.: volcaniclastic sandstone, ANF: quartz amphibolite rock, C.P.: carbonaceous pelite, Con. $+\mathrm{Ph}$ : conglomerate with phosphate-rich nodules, $\mathrm{Pel}$. $+\mathrm{Ph}$ : black pelite with phosphatic nodules, $\mathrm{O}$ : orthogneiss. Compositions expressed in $\mathrm{wt} \%$ oxides. 
tively. The rocks are all peraluminous: (mean ASI is 1.4 for migmatites and 1.3 for granodiorites). The ratio $\mathrm{Fe} /$ $(\mathrm{Fe}+\mathrm{Mg}$ ) is quite constant, with an average of 0.73 . The $\mathrm{TiO}_{2}$ concentration is locally high, in the range $0.25-1.25 \%$, and $\mathrm{MnO}$, between 0.03 and $0.11 \%$. $\mathrm{P}_{2} \mathrm{O}_{5}$ can reach values of $0.55 \%$. Cordierite leucogranites have a $\mathrm{SiO}_{2}$ content between 62.98 and $76.32 \%$. They are highly peraluminous (ASI $=1.3$ ) and tend to be grouped on the cordierite field of the AFM diagram. Restites are depleted in $\mathrm{SiO}_{2}$ and enriched in $\mathrm{TiO}_{2}$, $\mathrm{Al}_{2} \mathrm{O}_{3}$ and $\mathrm{CaO}$. Orthogneisses have a composition very close to that of the migmatites, except for their enrichment in $\mathrm{Ca}$, in which they resemble the granodiorites, and in $\mathrm{Na}$. Figure 5 shows the compositional variations. There is a trend in enrichment for $\mathrm{TiO}_{2}, \mathrm{Al}_{2} \mathrm{O}_{3}, \mathrm{FeO}$, $\mathrm{MgO}$ and content of $\mathrm{H}_{2} \mathrm{O}$ (measured as Loss on Ignition) from the most evolved materials to the restites.

The major-element composition of the postulated protolith (SGC) is close to that for average migmatite and is enriched in $\mathrm{FeO}$ and $\mathrm{MgO}$, but depleted in $\mathrm{Na}_{2} \mathrm{O}$ and $\mathrm{CaO}$. Major-element compositions of the orthogneisses are between those of migmatites and the SGC.

The trace-element variation is portrayed in spider diagrams (Fig. 6), with data from this study normalized to the upper continental crust (Taylor \& McLennan 1985). The granodiorites are very similar to the migmatites, and reveal a depletion of $\mathrm{B}, \mathrm{Li}, \mathrm{Sc}, \mathrm{V}$ and $\mathrm{S}$ compared to them. The depletion of volatiles is attributed to consumption of these components in the generation of melt. Enrichment of $\mathrm{Zr}, \mathrm{Mo}, \mathrm{Pb}$, Th and $\mathrm{Sn}$ has to do with the retention of these elements in accessory minerals, hosted in restite that remained as enclaves in the generation of granodiorite anatectic melts. Restites concentrate $\mathrm{Li}, \mathrm{Rb}, \mathrm{Sc}, \mathrm{V}, \mathrm{Ni}, \mathrm{Cu}, \mathrm{Y}, \mathrm{Zr}, \mathrm{Nb}, \mathrm{Mo}, \mathrm{Hf}$, $\mathrm{Ta}, \mathrm{Th}, \mathrm{U}, \mathrm{Sn}$ and $\mathrm{Ga}$. This enrichment is compensated by the depletion of the same elements in the leucogranites. Boron, as in the case of granodiorites, was lost in the melting process and it is depleted in both restites and leucogranites (Acosta et al. 2000).

The total REE content (Table 2, Fig. 7) in the mesocratic migmatites is rather high for this type of lithology. Chondrite-normalized patterns are very similar for all samples; they are characterized by a relatively strong fractionation of light rare-earth elements (LREE) against heavy rare-earth elements $(H R E E)\left(\mathrm{La}_{N} / \mathrm{Lu}_{\mathrm{N}}\right.$ in the range 11-36). All show a large negative anomaly for $\mathrm{Eu}\left(\mathrm{Eu} / \mathrm{Eu}^{*}\right.$ in the range 0.43-0.73). A similarity of the REE spectrum of migmatites and of Post-Archean Australian Shales (PAAS, McLennan 1989) supports the interpretation of a sedimentary precursor for the migmatites.

Among the products of anatexis, different chondritenormalized $R E E$ patterns are observed for granodiorites compared to the leucogranites. Total REE contents of granodiorites are high, matching those for the migmatites, and chondrite-normalized patterns show the same features. Fractionation of LREE versus HREE is strong $\left(\mathrm{La}_{N} / \mathrm{Lu}_{\mathrm{N}}=26\right)$, and the rocks also have a sig- nificant $\mathrm{Eu}$ anomaly $\left(\mathrm{Eu} / \mathrm{Eu}^{*}=0.53\right)$. For the leucogranites, the total REE contents are lower than in the granodiorites and mesocratic migmatites. Chondritenormalized patterns show significant differences, and most plot beneath the PAAS spectrum (Bea 1991, Pereira 1992).

The orthogneisses reveal an enrichment in almost all trace elements monitored, compared to the migmatites. The most striking depletions are observed in $\mathrm{B}, \mathrm{Li}, \mathrm{V}$, $\mathrm{Co}$ and $\mathrm{Zn}$ (Table 3). There is an enrichment in light rare-earth elements, and small Eu anomaly $\left(\mathrm{Eu} / \mathrm{Eu}^{*}=\right.$ 0.86) (Fig. 7).

Sillimanite-rich restites have very high $R E E$ contents; fractionation is again very high $\left(\mathrm{La}_{N} / \mathrm{Lu}_{N}=33\right)$, and the negative Eu anomaly is pronounced $\left(\mathrm{Eu} / \mathrm{Eu}^{*}=\right.$ 0.17 ) (Fig. 7). The REE are controlled mainly by the biotite, which enclose many of the trace element-bearing accesories.

We have compared the composition of the PNAC rock units with those of the SGC in terms of trace elements. The migmatites define a similar trend, but there is a conspicuous enrichment in U in the SGC. U depletion during anatexis was noted by Dostal \& Capedri (1978), as U is not located in accessory minerals or in the crystal structures of the major rock-forming minerals. It is readily leached out by migrating hydrous fluids. Granodiorites have the same trace-element pattern as the migmatites, marked by low values of $\mathrm{Li}$, but high $\mathrm{K} / \mathrm{Rb}, \mathrm{Sr}, \mathrm{Ba}$ and $\mathrm{Pb}$ (Fig. 6). In the case of the cordierite leucogranites, these differences could be due to the mobile behavior of alkali feldspar and cordierite, and the location of biotite in the restite.

The REE pattern for the SGC correlates with a pattern for metasedimentary protoliths. It is almost parallel to that of the PAAS, and those of the mesocratic migmatites and granodiorites also are similar, although there is a general depletion in HREE. For the leucogranites, the observed patterns are variable, although they invariably plot below the pattern of the other rock types.

Oxygen isotope analysis of the main lithologies from the PNAC and the SGC reveals that the highest values are found in the migmatites $\left(\delta^{18} \mathrm{O}=16 \%\right.$ ) and the SGC rocks $\left(\delta^{18} \mathrm{O}=14.1 \%\right.$ o). For the orthogneiss, we obtained a $\delta^{18} \mathrm{O}$ value of $12.3 \%$. The lowest values were obtained for the anatectic products from the migmatites $(11.5 \%$ o for cordierite leucogranites, down to 9.6 for granodiorites). Data for the migmatites and SGC resemble those for metasedimentary rocks (Kempton \& Harmon 1992) and suggest a pelite-rich source. The values obtained for the Peña Negra rocks indicate a heterogeneous evolution in the path of production of a granitic fraction, from a metasedimentary source to pure melts; the residue from partial melting has an important role, as bulk composition and hence, mineralogy, determine variations in the isotopic composition.

The ${ }^{87} \mathrm{Sr} /{ }^{86} \mathrm{Sr}$ initial ratios are 0.7071 for the migmatites, 0.7096 for the granodiorites and 0.7111 for 

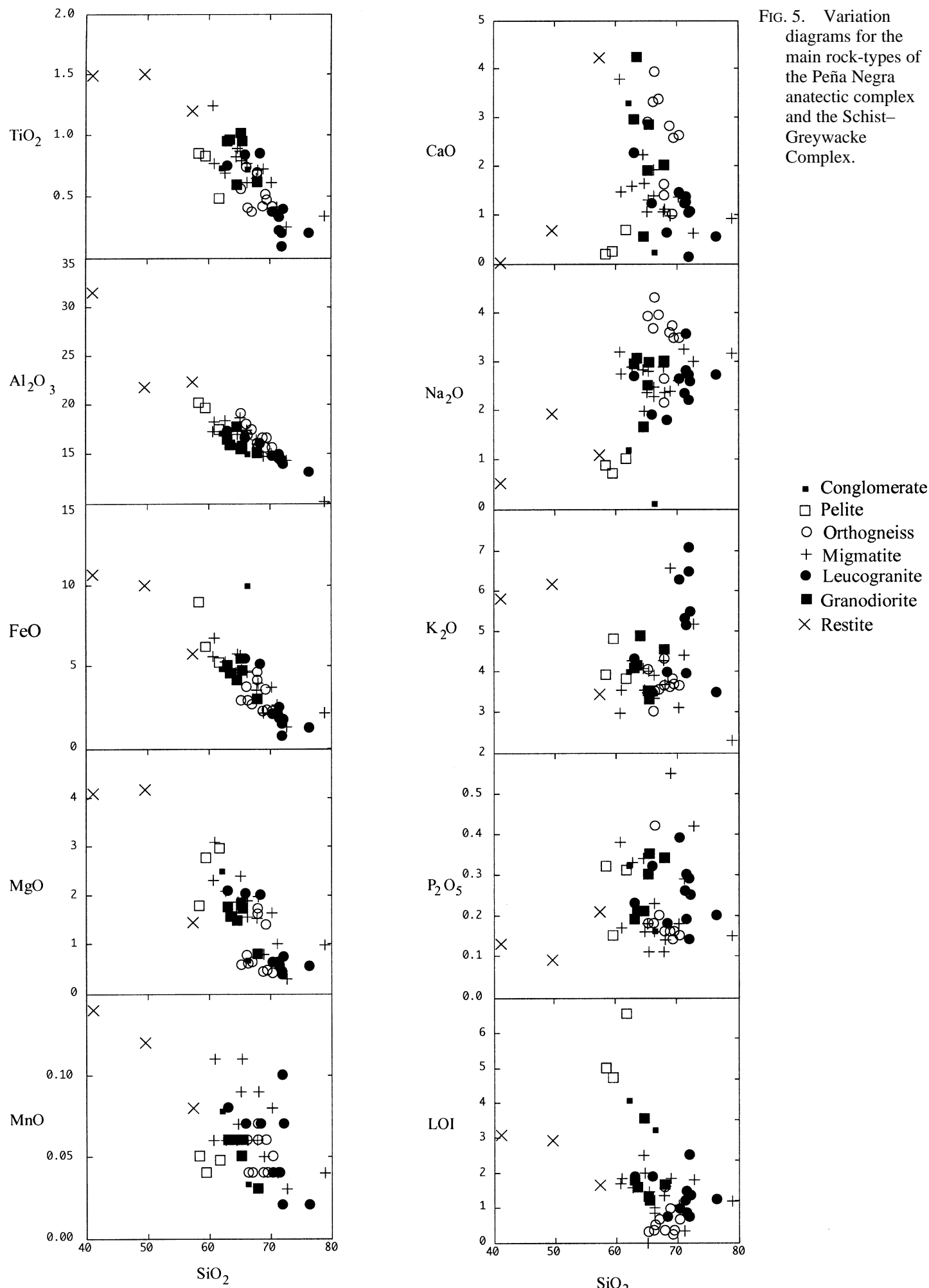
10.00

1.00

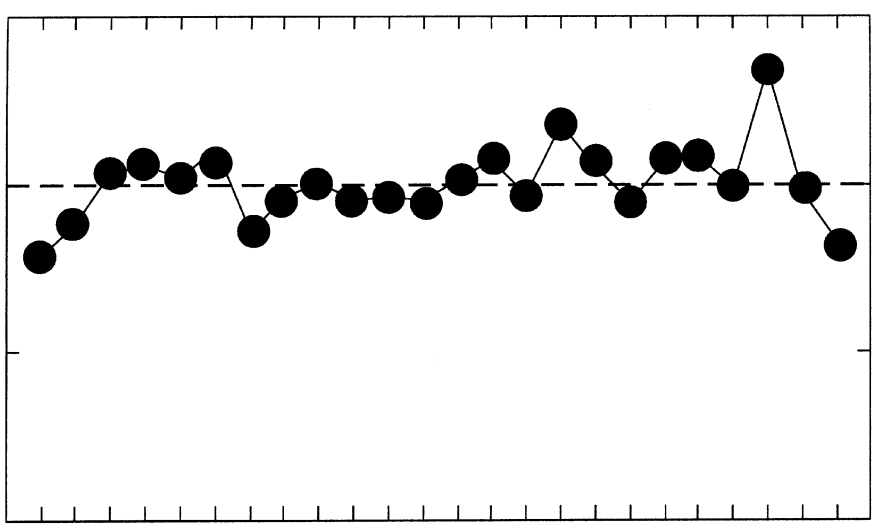

B Li Rb Be Sr Ba Sc V Co Ni CuZnY Zr Nb MoHfTa Pb Th U Sn Ga S

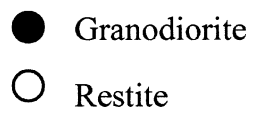

- Leucogranite

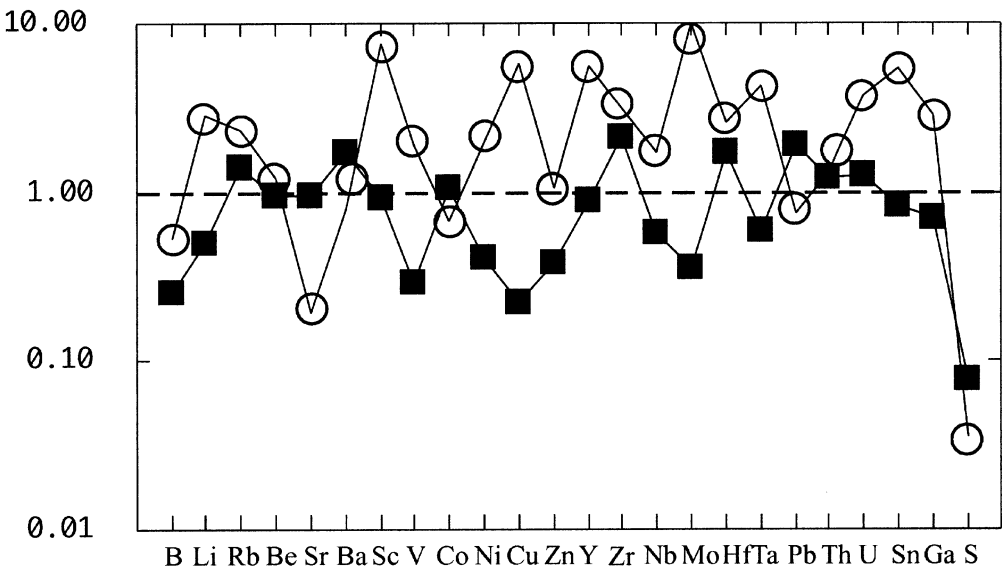

FIG. 6. Spidergram showing average trace-element concentrations, normalized to average trace-element data for the Schist-Greywacke Complex.

the leucogranites (Pereira et al. 1992). Further studies in geochronology involving $\mathrm{U}-\mathrm{Pb}$ in single-crystal zircon and $\mathrm{Nd}-\mathrm{Sm}$ in garnet will facilitate correlation of these rocks with other granitic rocks in the Spanish Central System (Barbero 1995).

\section{Petrogenetic duality and evolution of the complex}

Whole-rock $\mathrm{Rb}-\mathrm{Sr}$ dating was done on the main rock types of the Peña Negra complex (Pereira et al. 1992): migmatites and orthogneisses, $528 \pm 14 \mathrm{Ma}$, and granodiorites, $310 \pm 6 \mathrm{Ma}$. Granodiorites represent the most important product of anatexis of the migmatites, with respect to volume, and their age also dates the most intense period of partial melting of the Complex. Cordierite leucogranites gave an age in the range of 305 and $295 \mathrm{Ma}$, which corresponds to the late extensional episode of the orogeny.

The second phase of the Hercynian orogeny had a very important role in the generation of melt. This phase 

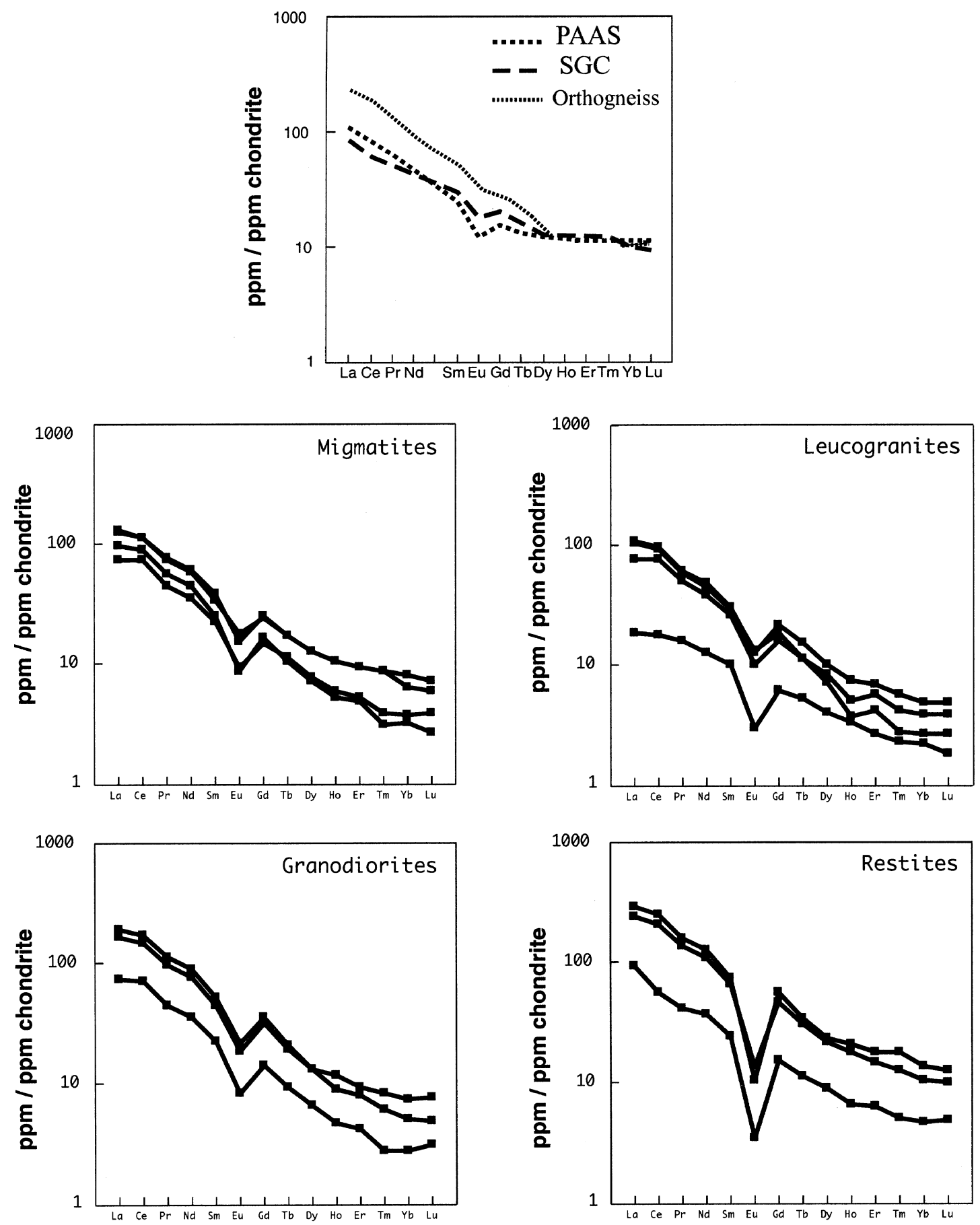

FIG. 7. Average concentrations of the rare-earth elements $(R E E)$ in the rocks of the Peña Negra anatectic complex and the Schist-Greywacke Complex, normalized to chondritic abundances. The protolith pattern is compared to the PAAS pattern. 
was the response to a contractional stage, and was translated into subhorizontal structures. In a general scheme of the PNAC, granodiorites define subhorizontal sheets of 1 to $10 \mathrm{~km}$ length (Fig. 2 of Pereira \& Bea 1994) and can reach $200 \mathrm{~m}$ in thickness. Subhorizontal structures affect both the migmatites and the granodiorites. It is clear that these structures acted as conduits for fluids and volatiles that promoted the partial melting and controlled the geometry of the melt (Pereira \& Shaw 1999, Acosta et al. 2000). A later extensional event produced the collapse of the migmatitic series. Locally, the planar fabric was affected by subvertical folding and subvertical shear zones (Bea \& Moreno-Ventas 1985, Bea 1985, Díez Balda et al. 1990).

Mesocratic migmatites have a uniform low-pressure paragenesis: quartz + plagioclase + alkali feldspar + biotite + cordierite \pm sillimanite. In a very specific area of the PNAC (see above), garnet has been identified as a minor phase, invariably related to mesocratic migmatites of the schlieren facies (Pereira 1992). Garnet-biotite and garnet-cordierite geothermobarometry reveals that the principal metamorphic episode occurred between $\mathrm{T} \approx 750$ and $800^{\circ} \mathrm{C}$ at a constant pressure of about 4 kbar (Pereira 1998). Melting started under lower-temperature conditions than the incongruent melting of biotite (LeBreton \& Thompson 1988, Vielzeuf \& Holloway 1988). Cordierite is a dominant phase in all the rock types; the availability of this mineral at the beginning of anatexis increased the melt fraction owing to its effect on lowering the solidus temperature in the haplogranitic systems at low pressure [see Pereira \& Bea (1994) and references therein].

Textural observations are critical in a mass-balance study intended to evaluate the anatectic mode of pro-

TABLE 2. TRACE-ELEMENT CONCENTRATIONS (ppm) IN SELECTED SAMPLES FROM THE PEÑA NEGRA ANATECTIC COMPLEX

LO-18 LO-25 LO-16 LO-3 B-516 LO-17 LO-23 LO-28 LO-29 LO-30 LO-5 LO-7 LO-8 LO-9

\begin{tabular}{|c|c|c|c|c|c|c|c|c|c|c|c|c|c|c|}
\hline & \multicolumn{4}{|c|}{ Migmatites } & \multicolumn{3}{|c|}{ Granodiorites } & \multicolumn{4}{|c|}{ Cordierite leucogranites } & \multicolumn{3}{|c|}{ Restites } \\
\hline & 4.2 & 5.8 & 5.2 & 124.3 & 15.9 & 6.9 & 16.9 & 13.8 & 6.2 & 11.2 & 4.5 & 21.7 & 25.8 & 8.5 \\
\hline $\mathrm{Li}$ & 63.09 & 63.93 & 52.5 & 8137.59 & 54.31 & 63.61 & 17.00 & 40.35 & 42.47 & 41.15 & 34.28 & 139.43 & 390.001 & 134.57 \\
\hline $\mathrm{Rb}$ & 83.811 & 124.82 & 202.0 & 7169.62 & 197.65 & 200.97 & 109.64 & 233.12 & 232.14 & 166.78 & 174.92 & 120.31 & 510.293 & 356.91 \\
\hline $\mathrm{Be}$ & 2.24 & 1.13 & 1.3 & $8 \quad 3.16$ & 3.86 & 1.05 & 2.70 & 3.04 & 1.51 & 2.49 & 0.56 & 1.66 & 3.17 & 2.36 \\
\hline $\mathrm{Sr}$ & 143.741 & 115.86 & 274.3 & 3140.26 & 182.53 & 263.05 & 107.55 & 172.95 & 189.42 & 152.59 & 123.36 & 8.32 & 22.54 & 66.42 \\
\hline $\mathrm{Ba}$ & 482.222 & 272.01 & 418.1 & 0546.60 & & & 513.64 & 928.00 & & & & 178.63 & 373.32 & 492.61 \\
\hline $\mathrm{Sc}$ & 13.18 & 26.87 & 14.0 & $6 \quad 16.09$ & 4.81 & 19.69 & 2.78 & 3.26 & 3.81 & 49.23 & & 26.16 & n.d. & 51.17 \\
\hline V & 99.41 & 99.40 & 84.8 & 79.47 & 93.86 & 72.98 & 57.47 & 23.79 & 25 & 28.75 & 27.22 & 259.57 & 318.31 & 207.95 \\
\hline Co & 60.01 & 50.57 & 55.9 & 46.62 & 74.20 & 45.75 & 40.80 & 57.92 & 61.88 & 46.30 & 62.01 & 22.65 & 39.34 & 46.97 \\
\hline $\mathrm{Ni}$ & 15.70 & 18.78 & 10.5 & $2 \quad 13.72$ & 13.95 & 11.05 & 10.8 & & & & 5.87 & & & 24.42 \\
\hline $\mathrm{Cu}$ & 28.71 & 26.73 & 18.3 & $6 \quad 25.83$ & 27.78 & 17.68 & 16 & & & & 5.01 & 106.37 & 27.34 & 25.09 \\
\hline $\mathrm{Zn}$ & 148.591 & 121.14 & 117.2 & 96.63 & 104.03 & 98.70 & 83.62 & 43.74 & 40.44 & 43.34 & 57.86 & 156.24 & & 175.63 \\
\hline $\mathrm{Y}$ & 13.07 & 11.19 & 28.5 & 26.81 & 29.24 & 22.77 & 10.35 & 21.61 & 12.47 & 14.54 & 21.23 & 11.17 & & 44.74 \\
\hline $\mathrm{Zr}$ & 56.91 & 33.64 & 20.5 & 963.82 & 49.43 & 57.69 & 75.17 & 86.68 & 78.90 & 109.45 & 91.24 & 223.39 & 280 & 130.41 \\
\hline $\mathrm{Nb}$ & 13.09 & 20.73 & 20.6 & $6 \quad 14.25$ & 16.23 & 15.99 & 11. & & & & 13.69 & 42.71 & 56 & 43.85 \\
\hline Mo & & 0.43 & & 0.97 & & 4.54 & & & & & & 103 & & 0.36 \\
\hline $\mathrm{Hf}$ & & 1.56 & 1 & 2.36 & 2.20 & 2.17 & 2.6 & 3.03 & & & & & & 4.18 \\
\hline $\mathrm{Ta}$ & & 1.30 & & 1.16 & 1.0 & 1.15 & & & 0.7 & & & & & 3.50 \\
\hline $\mathrm{Pb}$ & 16.76 & 16.85 & 15.7 & 22.24 & 20.85 & 23.07 & 29 & 32. & 33. & & 29 & .09 & 8.38 & 14.22 \\
\hline Th & 6.94 & 10.53 & 9 & 13.10 & 14.97 & 20.49 & 9.05 & 12.12 & 12.53 & 11.75 & 12 & 10 & 19. & 19.98 \\
\hline $\mathrm{U}$ & 3.10 & 2.94 & 1.7 & 2.75 & 2.45 & 2.89 & 2.23 & 3.81 & 3.4 & 50 & & & & 7.20 \\
\hline Sn & 7.48 & 3.44 & 2. & 7.50 & 4.43 & 3.67 & 64.8 & 2.72 & 3.20 & 4.21 & & & 16. & 10.81 \\
\hline $\mathrm{Ga}$ & 25.12 & 29.77 & 28.4 & $9 \quad 23.41$ & 27.45 & 25.28 & 19.59 & 18.64 & 17.72 & 18.74 & 20.55 & 67.17 & 61.47 & 49.33 \\
\hline S & 2008 & 6596 & 6594 & $2199 \quad 1$ & $\begin{array}{ll}717 & 1\end{array}$ & 1852 & 337 & 126 & 108 & 350 & 294 & 20 & n.d. & 38.22 \\
\hline $\mathrm{La}$ & 27.06 & 36.32 & 47.7 & $5 \quad 46.07$ & 62.05 & 70.68 & 27.40 & 39.40 & 38.14 & 28.75 & 7.00 & 34.25 & 108 & 90.82 \\
\hline $\mathrm{Ce}$ & 70.34 & 85.37 & 108.2 & 4110.19 & 141.77 & 163.52 & 67.55 & 92.83 & 90.03 & 73.54 & 17.22 & 54.97 & 245.94 & 200.30 \\
\hline $\operatorname{Pr}$ & 18 & 7.80 & 10. & 110.38 & 13.26 & 15.34 & & 8.48 & & 6.84 & & 5.72 & 22.22 & 18.82 \\
\hline $\mathrm{Nd}$ & 25.96 & 32.06 & 42.1 & 43.94 & 54.78 & 64.06 & 25.82 & 34.14 & 31.53 & 27.48 & 9.13 & 26.20 & 90. & 78.10 \\
\hline $\mathrm{Sm}$ & & & & 9.07 & 10.60 & 12.21 & & 7.03 & & & & .73 & 14 & 15.26 \\
\hline $\mathrm{Eu}$ & & 0.76 & & 1.37 & 1.64 & 1.89 & 0.73 & & & 0.89 & & 0.30 & 0.91 & 1.18 \\
\hline $\mathrm{Gd}$ & 4.62 & 5.20 & & 7.87 & & 11.09 & & 6.71 & & 4.96 & 1.88 & 4.77 & 17.16 & 14.41 \\
\hline $\mathrm{Tb}$ & 0.65 & 0.62 & 0.9 & 1.01 & 1.13 & 1.22 & 0.54 & 0.88 & 0.65 & 0.67 & & 0.67 & 1.99 & 1.79 \\
\hline Dy & 2.90 & 2.76 & 4.8 & 4.87 & 5.02 & 4.97 & 2.53 & 3.93 & 2.76 & 3.14 & 1.54 & 3.42 & 9.14 & 8.27 \\
\hline Ho & & 0.45 & & 0.88 & 1.00 & 0.78 & 0.40 & 0.63 & 0.32 & 0.44 & 0.28 & 0.57 & 1.77 & 1.55 \\
\hline $\mathrm{Er}$ & & 1.22 & & 2.33 & & 1.99 & & 1.72 & 1.05 & 1.41 & 0.66 & 1.61 & 4.50 & 3.67 \\
\hline $\mathrm{Tm}$ & 0.14 & 0.11 & 0.3 & 0.31 & 0.30 & 0.22 & 0.10 & 0.20 & 0.10 & 0.15 & 0.08 & 0.18 & 0.64 & 0.46 \\
\hline $\mathrm{Yb}$ & 0.92 & 0.79 & 1.6 & 2.00 & 1.85 & 1.26 & 0.68 & 1.23 & 0.65 & 0.98 & 0.54 & 1.18 & 3.42 & 2.62 \\
\hline $\mathrm{Lu}$ & 0.15 & 0.10 & 0.2 & 0.27 & 0.29 & 0.19 & 0.12 & 0.19 & 0.10 & 0.15 & 0.07 & 0.19 & 0.49 & 0.38 \\
\hline $\mathrm{Rb} / \mathrm{S}$ & 0.58 & 1.08 & 0.7 & 1.21 & 1.08 & 0.76 & 1.02 & 1.35 & 1.23 & 1.09 & 1.42 & 14.46 & 22.64 & 5.37 \\
\hline
\end{tabular}


TABLE 3. TRACE-ELEMENT CONCENTRATIONS IN SELECTED SAMPLES OF ORTHOGNEISS

\begin{tabular}{|c|c|c|c|c|}
\hline & B-312 & B-374 & B-377 & B-378 \\
\hline B ppm & 4.4 & 3.9 & 5.5 & 5.7 \\
\hline $\mathrm{Li}$ & 36 & 68 & 37 & 36 \\
\hline $\mathrm{Rb}$ & 87 & 106 & 90 & 92 \\
\hline $\mathrm{Sr}$ & 224 & 237 & 241 & 223 \\
\hline $\mathrm{Ba}$ & 1539 & 1104 & 1799 & 1790 \\
\hline V & 81 & 50 & 34 & 26 \\
\hline $\mathrm{Cr}$ & 151 & 113 & 108 & 111 \\
\hline Co & 8 & 6 & 1 & 1 \\
\hline $\mathrm{Ni}$ & 32 & 16 & 13 & 11 \\
\hline $\mathrm{Cu}$ & 37 & 34 & 36 & 32 \\
\hline $\mathrm{Zn}$ & 68 & 78 & 46 & 70 \\
\hline $\mathrm{Y}$ & 38 & 31 & 36 & 36 \\
\hline $\mathrm{Zr}$ & 309 & 365 & 263 & 241 \\
\hline $\mathrm{Nb}$ & 14 & 19 & 12 & 12 \\
\hline $\mathrm{La}$ & 95.40 & 86.90 & 90.30 & 83.10 \\
\hline $\mathrm{Ce}$ & 183.20 & 180.28 & 170.10 & 193.10 \\
\hline $\mathrm{Nd}$ & 65.80 & 67.22 & 60.20 & 59.40 \\
\hline $\mathrm{Sm}$ & 15 & 15.09 & 14.13 & 17.20 \\
\hline $\mathrm{Eu}$ & 3.90 & 3.32 & 3.54 & 3.61 \\
\hline Gd & 8.95 & 10.11 & 12.03 & 11.41 \\
\hline Dy & 8.36 & 6.69 & 6.52 & 6.80 \\
\hline Ho & n.d. & n.d. & 2.69 & n.d. \\
\hline $\mathrm{Er}$ & 3.16 & 2.68 & n.d. & 2.75 \\
\hline $\mathrm{Yb}$ & 2.47 & 2.54 & 2.93 & 2.46 \\
\hline $\mathrm{Lu}$ & 0.40 & 0.40 & 0.40 & 0.44 \\
\hline $\mathrm{Rb} / \mathrm{Sr}$ & 0.39 & 0.45 & 0.37 & 0.41 \\
\hline
\end{tabular}

duction of PNAC granites. 1) Cordierite appears in different textural forms (Pereira \& Bea 1994). In the leucosome, it consists of euhedral crystals, suggesting a magmatic origin; in the melanosome, it forms xenomorphic crystals with a granoblastic texture, and surrounds garnet, as a consequence of retrograde metamorphism due to decompression. 2) In the melanosome, the association biotite + sillimanite + quartz never shows textural equilibrium. 3) The most common paragenesis in the melanosome and in the enclaves of restite is biotite + sillimanite + cordierite + ilmenite. Complete compositions of the PNAC rock-forming minerals can be found in Bea et al. (1994), and in Pereira \& Bea (1994).

The first stage in the metamorphic evolution is given by the pre-anatectic assemblage that occurs in areas near the PNAC, and in which similar rocks have not reached the "melt-in" isograd. They contain the association biotite + sillimanite + quartz without textural evidence of reaction.

The reaction among biotite, sillimanite and quartz in the melanosome suggests the $\mathrm{P}-\mathrm{T}$ conditions that permitted reaction (1) be totally displaced to the right:

$$
\mathrm{Bt}+\mathrm{Sil}+\mathrm{Qtz}=\mathrm{Crd}+\mathrm{Kfs}+\text { vapor }
$$

Adjustment of the mass balance for reaction (1) to correspond to the mineralogy of the PNAC granitic products can be found in Pereira \& Bea (1994). The path of metamorphism followed by the PNAC went from melt- ing of the protolith, to the retrograde conditions, which generated cordierite + biotite from garnet (Pereira 1998).

\section{Petrogenetic duality for the granitic products}

The two kinds of cordierite-bearing granitic rocks (leucogranite and granodiorite) result from the anatexis in migmatites in the PNAC. The most acceptable explanation of the field, petrographic and chemical observations is that subautochthonous granodiorites were generated from a hybrid source composed of mesocratic migmatites and orthogneisses (Bea \& Pereira 1990) by partial melting. The small volume of residual rocks, which appear related to granodiorite, either as enclaves or sillimanite-rich rocks, suggests that restite-melt unmixing was inefficient. Subautochthonous granodiorites are directly related to subhorizontal shear-zones, where $\mathrm{H}_{2} \mathrm{O}$ (derived from an external source and from dehydration of micas) and volatiles (the role of boron in these rocks is explained in Pereira \& Shaw 1996, 1997, 1999) were concentrated. The importance of fault zones in concentrating $\mathrm{H}_{2} \mathrm{O}$ and hydrous fluids has been considered by many workers (e.g., Strong \& Hanmer 1981) with regard to their significance in promoting extensive melting. Development of the granodiorites was conditioned by the nature of the source rocks, and anatexis only occurred where the quartz-feldspar content exceeded a critical value. In this case, the melt fraction was higher than the Critical Melt Fraction $(\mathrm{CMF}=30$ vol. \%, Wickham 1987), and residual products were not separated. Applying the anatectic mixing model of Bea (1989), we suggest that a hybrid source made up of migmatites and orthogneisses would give a very low fraction of residual melt (see below). The ${ }^{87} \mathrm{Sr} /{ }^{86} \mathrm{Sr}_{i}$ values for the granodiorites agree with the idea of their generation through partial melting of migmatites. However, the lower $\delta^{18} \mathrm{O}$ values obtained for the granodiorite could be due to contamination with more basic rocks. Although mafic rocks have not been found in the area studied, gabbroic bodies, with an age of $415 \mathrm{Ma}$ (Moreno-Ventas et al. 1995) and $\delta^{18} \mathrm{O}=8.45 \%$ o (Pereira, unpubl. data), have been described in an area nearby. Further studies on these rocks are being carried out to understand the genesis of these granodiorites and a possible interaction with basic rocks at a deeper level (Villaseca et al. 1998).

The mechanism proposed for the generation of granodiorite contrasts with that for the cordierite leucogranites, whose mineralogy, textures and chemical composition are compatible with the segregation of a pure melt, largely devoid of restite material (Bea 1991). In this case, the critical melt fraction was not exceeded, perhaps because alkali feldspar and cordierite abundances played a limiting role, the source of leucogranites being locally depleted in these phases at this stage of anatexis. The segregation of leucogranites would yield a residue enriched in sillimanite and biotite, with some quartz and cordierite, which is represented by the 
restites. Melt extraction of the leucogranites represents a pure segregated fraction.

Therefore, the two different granitic rocks of anatectic origin found in the PNAC correspond to two different petrogenetic mechanisms of segregation of melt from restite: low-melt-fraction granite in the case of the leucogranites and high-melt-fraction granite in the case of the granodiorites (both terms taken from Wickham 1987). They never grade into each other and in both cases, the existence of a "fertile" source is the important factor controlling the segregation of one or the other kind of granitic fraction, although there is a close spatial and temporal association between the granitic rocks and shear structures, as described by Barbarin (1996, 1999). This situation is common within the Hercynian belt (Holtz 1989, Holtz \& Barbey 1991) and is probably one of the causes of the characteristic duality in granitic rocks throughout the European Variscan belt.

\section{Geodynamic evolution}

On the basis of the geothermobarometric studies on the PNAC migmatites, a P-T trajectory is obtained indicating that the metamorphic paroxysm took place under maximum conditions of $\mathrm{T} \approx 750^{\circ} \mathrm{C}$ and $\mathrm{P} \approx 4 \mathrm{kbar}$. Subsequently, a drop in temperature and pressure took place, and retrograde metamorphism occurred under minimum conditions of $\mathrm{T} \approx 500^{\circ} \mathrm{C}$ and $\mathrm{P} \approx 1-2 \mathrm{kbar}$ (Pereira 1998).The same clockwise P-T path followed by the PNAC materials has been described for many other nearby Hercynian regions (e.g., Gil Ibarguchi \& Martínez 1982, Barbero 1995, Yenes 1996). This path was responsible for the generation of important volumes of peraluminous granitic magma and has been interpreted to result from brief intervals of rapid tectonic thickening, followed by exhumation of materials (Hollister 1994). The thickening was the result of thrusting during the contractional first phases of the Hercynian orogeny. As a response to these events, granodiorite sheets were produced by partial melting of the migmatites. An extensional collapse at the end of the orogeny had the effect of decreasing pressure to produce the small bodies of leucogranite from a source already depleted in fertile components.

\section{Discussion AND Conclusions}

Migmatites of the Peña Negra anatectic complex were produced by the partial melting of a highly heterogeneous protolith, the Schist-Greywacke Complex, only where a high volume of orthogneisses was available. Owing to this heterogeneity, it is difficult to calculate an average composition for the SGC, but based on the relative abundance of rock types, an attempt to estimate its average composition has been made:
$\mathrm{SGC}=\{(15 *$ Black pelite $)+(2 *$ Sandstone $)$

$+(3 *$ Conglomerate $)+[0.5 *($ volcaniclastic

+ amphibolitic rocks)]\}/38.5

Rock types mentioned in the formulae represent the average composition of each one. Adjusting the mass balance to calculate the composition of the migmatites, following the method described by Bea (1989), we get the approximate expression:

$$
\begin{aligned}
& \text { Migmatites }=0.763 \mathrm{SGC}+0.049 *(\text { Quartz } \\
& + \text { Orthoclase + Albite + Anorthite })
\end{aligned}
$$

Gneisses have been dated by U-Pb zircon geochronology, giving Cadomian to Cambrian ages (Leterrier \& Noronha 1998). More recently, Fernández-Suárez et al. (1999) have proposed that basement rocks range in age from Paleoproterozoic to Neoproterozoic, on the basis of zircon found in orthogneisses from northwestern Iberia. Homogenization of the protolith $(\mathrm{SGC}+$ orthogneisses) prior to the Hercynian anatexis gave rise to a compositional mixture, in which all the rocks (except for the most extreme lithologies, e.g., sandstones and limestones, that are found now as enclaves within the PNAC materials) progressively acquired essentially uniform characteristics.

Migmatites are the result of anatexis during the Hercynian orogeny, involving the breakdown of hydrous minerals. The existence of cordierite and the addition of boron and other volatile species led to lowering the solidus temperature, and the minimum-melt composition was shifted to the left of the melt-production curve, producing peraluminous granodiorites and, at lower temperatures, leucogranites (Pereira \& Bea 1994, Guillot \& Le Fort 1995).

The composition of the granodiorite lies between that of migmatite and the orthogneiss precursor, suggesting a hybrid source in its production, with little change in bulk composition. This idea agrees with an episode of wholesale melting, with very little fractional crystallization. In contrast, the composition of the leucogranite supports an origin from a small degree of melting of migmatite, leaving a residue impoverished in $\mathrm{SiO}_{2}$ and $\mathrm{Na}_{2} \mathrm{O}$, and enriched in $\mathrm{TiO}_{2}, \mathrm{Al}_{2} \mathrm{O}_{3}$ and $\mathrm{CaO}$. The surprising feature of the leucogranites is the enrichment in $\mathrm{K}$. The melanosome of the migmatites also is enriched in $\mathrm{K}$, so we can deduce that the leucogranites were produced by remelting migmatites where there was an enrichment in the melanocratic component, the breakdown of biotite providing the excess $\mathrm{K}$ for leucogranite generation.

The levels of concentration of the trace elements and $R E E$ in the migmatites and granitic products provide evidence for the anatectic origin of the latter. The chemical differences between the granodiorites and leucogranites must be due to the composition of the source 
rocks. There is no place in the area where these two rock units grade into each other. Migmatites were formed from a very heterogeneous source, and the different layers defined by the proportions of feldspathic components have different $R E E$ patterns in the anatectic products (Bea 1991, Johannes et al. 1995). The complementarity of some trace element anomalies of restites and leucogranite, vis-à-vis the migmatites, corroborates the anatectic hypothesis for the generation of the leucogranites. If there is a residue enriched in $R E E$ to compensate for the depletion of the leucogranites in these elements, then the leucogranites are likely to have formed from source-rocks with the characteristics of the migmatites. The enrichment of this residue in $R E E$ is mainly due to the high concentration of biotite, which is a conspicuous host for accessory phases, mainly zircon (Nabelek \& Glascock 1995). Such a residue might be represented by the sillimanite-rich rocks from the Peña Negra complex. The anatectic model proposed for the generation of the granites (Bea 1989, Pereira 1992) is only satisfied where the chemical and mineralogical composition of the granitic products is added to the composition of these sillimanite-rich rocks.

\section{ACKNOWLEDGEMENTS}

Brian Upton is greatly acknowledged for his suggestions and his help in giving a proper sense to our Spanglish version. B. Bonin and B. Barbarin reviewed a previous version of the manuscript. We thank E. Sawyer and F. Breaks for their helpful reviews, and R.F. Martin for the editorial handling. Some analyses were done at McMaster University and the University of Saskatchewan.

\section{REFERENCES}

Acosta, A., Pereira, M.D. \& Shaw, D.M. (2000): Influence of volatiles in the generation of crustal anatectic melts. $J$. Geochem. Explor. 69-70, 339-342.

Barbarin, B. (1996): Genesis of the two main types of peraluminous granitoids. Geology 24, 295-298.

(1999): A review of the relationships between granitoid types, their origins and their geodynamic environments. Lithos 46, 605-626.

BARBERO, L. (1995): Granulite-facies metamorphism in the Anatectic Complex of Toledo, Spain: late Hercynian tectonic evolution by crustal extension. J. Geol. Soc. London 152, 365-382.

BEA, F. (1985): Los granitoides hercínicos de la mitad occidental del Batolito de Avila (Sector de Gredos); aproximacion mediante el concepto de superfacies. Revista de la Real Academia de Ciencias Físicas, Exactas y Naturales de Madrid 79, 549-572.
(1989): A method for modelling mass-balance in partial melting and anatectic leucosome segregation. $J$. Metamorph. Geol. 7, 619-628.

(1991): Geochemical modelling of low melt-fraction anatexis in a peraluminous system: the Peña Negra Complex (central Spain). Geochim. Cosmochim. Acta 55, $1859-1874$.

\& Moreno-Ventas, I. (1985): Estudio petrológico de los granitoides del área centro-sur de la Sierra de Gredos (Batolito de Avila, Sistema Central Español). Studia Geologica Salmanticensia 20, 137-174.

\& Pereira, M.D. (1990): Estudio petrológico del Complejo Anatéctico de la Peña Negra, Batolito de Avila, España central. Rev. Soc. Geol. España 3, 87-103.

\& STROH, A. (1994): Mineral/leucosome trace-element partitioning in a peraluminous migmatite (a laser ablation-ICP-MS study). Chem. Geol. 117, 291-312.

Beetsma, J.J. (1995): The Late Proterozoic/Paleozoic and Hercynian Crustal Evolution of the Iberian Massif, $N$ Portugal, as Traced by Geochemistry and $\mathrm{Sr}-\mathrm{Nd}-\mathrm{Pb}$ Isotope Systematics of Pre-Hercynian Terrigenous Sediments and Hercynian Granites. Ph.D. thesis, Vrije Universiteit, Amsterdam, The Netherlands.

Clayton, R.N. \& Mayeda, T.K. (1963): The use of bromine pentafluoride in the extraction of oxygen from oxides and silicates for isotopic analysis. Geochim. Cosmochim. Acta 27, 43-52.

DíEz BALDA, M.A. (1980): La sucesión estratigrafíca del Complejo Esquisto-Grauváquico al sur de Salamanca. Estudios Geológicos 36, 131-138.

Vegas, R. \& GonZÁlez Lodeiro, F. (1990): Central Iberian Zone: autochthonous sequences: structure. In Pre-Mesozoic Geology of Iberia (R.D. Dallmeyer \& E. Martínez García, eds.). Springer Verlag, Berlin, Germany (172-188).

Dostal, J. \& CAPEDRI, S. (1978): Uranium in metamorphic rocks. Contrib. Mineral. Petrol. 66, 409-414.

Fernández-SuÁrez, J., GutiérReZ-Alonso, G., Jenner, G.A. \& Tubrett, M.N. (1999): Crustal sources in Lower Palaeozoic rocks from NW Iberia: insights from laser ablation U-Pb ages of detrital zircons. J. Geol. Soc. London 156, 1065-1068.

Fuster, J.M. \& Villaseca, C. (1979): Migmatización en las series metamórficas de la vertiente norte de la Sierra de Guadarrama. Estudios Geológicos 35, 285-290.

García de Figuerola, L.C. \& Franco, M.P. (1975): Las formaciones infraordovícicas y el borde de los granodioritas al Este de Guijuelo (Salamanca). Estudios Geológicos 31, 487-500. 
Gil Ibarguchi, I. \& Martínez, F.J. (1982): Petrology of garnet - cordierite - sillimanite gneisses from the El Tormes thermal dome, Iberian Hercynian Foldbelt (W Spain). Contrib. Mineral. Petrol. 80, 14-24.

Guillot, S. \& Le Fort, P. (1995): Geochemical constraints on the bimodal origin of High Himalayan leucogranites. Lithos 35, 221-234.

HoLTZ, F. (1989): Importance of melt fraction and source rock composition in crustal genesis: the example of two granitic suites of northern Portugal. Lithos 24, 21-35.

\& BARBEY, P. (1991): Genesis of peraluminous granites. II. Mineralogy and chemistry of the Tourem complex (north Portugal). Sequential melting vs. restite unmixing. J. Petrol. 32, 959-978.

Hollister, L.S. (1994): Clockwise P-T-t paths: the view from the Coast Orogen, British Columbia. Trans. Am. Geophys. Union (Eos) 75(16), 186 (abstr.).

Ibarrola, E., Villaseca, C., Vialette, Y., Fuster, J.M., Navidad, M., Peinado, M. \& Casquet, C. (1987): Dating of Hercynian Granites in the Sierra de Guadarrama (Spanish Central System). In Geología de los Granitoides y Rocas Asociadas del Macizo Hespérico (F. Bea et al., eds.). Rueda, Madrid, España (377-383).

Johannes, W., Holtz, F. \& Möller, P. (1995): REE distribution in some layered migmatites: constraints on their petrogenesis. Lithos 35, 139-152.

Julivert, M., Fontboté, J.M., Riveiro, A. \& Conde, L.N. (1972): Mapa tectónico de la Península Ibérica y Baleares (escala 1:4,000,000). Instituto Geológico y Minero de España, Madrid, Spain.

KemPton, P.D. \& HARMON, R.S. (1992): Oxygen isotope evidence for large-scale hybridization of the lower crust during magmatic underplating. Geochim. Cosmochim. Acta 56, 971-986.

Le Breton, N. \& Thompson, A.B. (1988): Fluid-absent (dehydration) melting of biotite in metapelites in the early stages of crustal anatexis. Contrib. Mineral. Petrol. 99, 226-237.

Leterrier, J. \& Noronha, F. (1998): Evidências de um plutonismo calcoalcalino Cadomiano e de um magmatismo tipo MORB no Complexo Metamórfico de Foz do Douro (Porto). V Congreso Nacional de Geología. IGMGeoFCUL, Lisbon, Portugal (B146-149).

Martínez García, E. \& Nicolau, J. (1973): Los terrenos infraordovícicos de la antiforma de Martinamor (Salamanca). Bol. Geol. y Mineral. 84, 407-418.

MCLellan, E.L. (1983): Contrasting textures in metamorphic and anatectic migmatites: an example from the Scottish Caledonides. J. Metamorph. Geol. 1, 241-262.

McLennan, S.M. (1989): Rare earth elements in sedimentary rocks: influence of provenance and sedimentary process.
In Geochemistry and Mineralogy of Rare Earth Elements (B.R. Lipin \& G.A. McKay, eds.). Rev. Mineral. 21, 169-200.

Moreno-Ventas, I., Rogers, G. \& Castro, A. (1995): The role of hybridization in the genesis of Hercynian granitoids in the Gredos Massif, Spain: inferences from Sr-Nd isotopes. Contrib. Mineral. Petrol. 120, 137-149.

NABelek, P.I. \& Glascock M.D. (1995): REE-depleted leucogranites, Black Hills, South Dakota: a consequence of disequilibrium melting of monazite-bearing schists. $J$. Petrol. 36, 1055-1071.

Nozal, F. \& Robles, R. (1988): Series y correlación de los materiales anteordovícicos en los Montes de Toledo y el Sur de Salamanca. II Congr. Geol. España, Soc. Geol. España (Granada) 1, 139-143.

Oczlon, M.S. \& Díez Balda, M.A. (1992): Contourites in laminated black shale facies of the Aldeatejada Formation (Precambrian/Cambrian boundary range, province of Salamanca, western Spain). Rev. Soc. Geol. España 5, 167-176.

PEREIRA, M.D. (1989): Migmatización diatexítica y la génesis de las granodioritas subautóctonas del Complejo Anatéctico de la Peña Negra, Batolito de Avila. M.Sc. thesis, Universidad de Salamanca, Salamanca, España.

(1992): El Complejo Anatéctico de la Peña Negra (Batolito de Avila): Un estudio de la anatexia cortical en condiciones de baja presión. $\mathrm{PhD}$ Thesis. Universidad de Salamanca, Salamanca, España.

(1998): Pressure and temperature conditions in the generation of an anatectic complex in central Spain: the Peña Negra complex. Petrology 6, 555-563.

\& BEA, F. (1994): Cordierite-producing reactions at the Peña Negra Complex, Avila batholith, central Spain: the key role of cordierite in low pressure anatexis. Can. Mineral. 32, 763-780.

Ronkin, Y. \& BEA, F. (1992): Dataciones Rb/Sr en el Complejo Anatéctico de la Peña Negra (Batolito de Avila, España Central): Evidencias de magmatismo prehercínico. Rev. Soc. Geol. España 5, 129-134.

\& SHAw, D.M. (1996): B and Li distribution in the Peña Negra complex: an alpha-track study. Am. Mineral. 81, 141-145.

$\&$ (1997): Behaviour of boron in the generation of an anatectic complex: the Peña Negra complex, central Spain. Lithos 40, 179-188.

$\&$ (1999). Relationship between geodynamics and generation of melt in central Spain. Phys. Chem. Earth A 24, 317-319.

RAMIREZ, J.A. \& GRUNDVIG, S. (2000): Causes of geochemical diversity in peraluminous granitic plutons: the Jálama pluton, Central-Iberian zone (Spain and Portugal). Lithos 50, 171-190. 
Rodríguez Alonso, M.D. (1985): El complejo esquistograuwáquico y el Paleozoico en el centro-oeste español. Acta Salmanticensia 51 (Universidad de Salamanca, Salamanca, Spain).

\& Alonso Gavilán, G., eds. (1995): Neoproterozoic - Lower Cambrian in the Central-Western part of the Iberian Peninsula. XIII Geol. Meet. on the W. of the Iberian Peninsula - Annual Int. Geol. Correlation Program, Project 319 Meet. - Regional Int. Geol. Correlation Program Project 320 Meet., Post-Conference Field Guide.

\& PAlacios, T. (1994): A paleogeographical outline of Upper-Median - Lower Cambrian in the Iberian Peninsula. Int. Geol. Correlation Program 319-376 (Nova Scotia), 1-2.

STRONG, D.F. \& Hanmer, S.K. (1981): The leucogranites of southern Brittany: origin by faulting, frictional heating, fluid flux and fractional melting. Can. Mineral. 19, 163176.

TAYloR, S.R. \& McLennan, S.M. (1985): The Continental Crust: its Composition and Evolution. Blackwell Scientific Publications, London, U.K.

Vidal, G., Palacios, T., Gámez-Vitaned, J.A., Díez Balda, M.A. \& GRANT, S.W.F. (1994): Neoproterozoic - early
Cambrian geology and palaeontology of Iberia. Geol. Mag 131, 729-765.

Vielzeuf, D. \& Holloway, J.R. (1988): Experimental determination of the fluid-absent melting relations in the pelitic systems. Consequences for crustal differentiation. Contrib. Mineral. Petrol. 98, 257-276.

Villaseca, C., BARbero, L. \& Rogers, G. (1998): Crustal origin of Hercynian peraluminous granitic batholiths of central Spain; petrological, geochemical and isotopic ( $\mathrm{Sr}, \mathrm{Nd})$ constraints. Lithos 43, 55-79.

WickHAM, S.M. (1987): The segregation and emplacement of granitic magmas. J. Geol. Soc. London 144, 281-297.

YENES, M. (1996): Estructura, geometría y cinemática del emplazamiento de los granitoides del área de la AlbercaBejar (Sistema Central Español, zona centro ibérica). Ph.D. thesis, Universidad de Salamanca, Salamanca, España.

Received April 5, 2000, revised manuscript accepted November 13, 2000 